\title{
FLUXOS IMIGRATÓRIOS DE LATINO-AMERICANOS: CIDADANIA TRANSNACIONAL
}

\author{
Célia Toledo Lucena ${ }^{1}$
}

\section{RESUMO}

Este artigo discute fluxos migratórios de sul e centro americano em contexto de globalização. Apresenta alguns resultados de investigações sobre mulheres em região metropolitana e fronteiriça. Assim, mulheres peruanas na cidade de São Paulo e mulheres nicaraguenses em Costa Rica são conteúdos de análise. O critério de escolha dos contextos baseou-se em dois tipos de destino mais favoritos entre latinoamericanos em migrações recentes. Conferir a feminização nos movimentos imigratórios e as formas de sobrevivência dessas mulheres nos respectivos espaços receptores, as re-significações do conceito de cidadania a partir das relações interétnicas e interculturais são alguns dos objetivos. Nos espaços sociais se constroem redes e laços que cruzam as fronteiras políticas ao estabelecer múltiplas relações familiares, sociais, políticas, religiosas e culturais. A transnacionalização, resultado da globalização, por sua vez, é permeada por controles migratórios, por conflitos, por fiscalizações em fronteiras internacionais, gerando novas questões socioeconômicas. As experiências de vida de alguns atores revelaram como o conceito de cidadania é re-construído na diversidade cultural, como reagem diante da convivência com distintas culturas, dos confrontos em espaços sociais que registram novos movimentos em continuidade à problemática que os respectivos grupos já possuíam no território de origem.

As metrópoles e as fronteiras na América Latina têm se apresentado como espaços de encontro entre o local e o global, de intercâmbio, conflitos e de relações interculturais. Mulheres nicaraguenses migram para Costa Rica em busca de melhores salários, de melhores serviços de saúde, porém muitas vezes, o desencanto motiva retornos. Já as peruanas instaladas na cidade de São Paulo utilizam a comida do país de origem como estratégia assertiva para a ganhar a vida e de serem reconhecidas culturalmente no país de destino. Na construção cultural da cidadania o(a) imigrante acentua aquilo que a cultura tem de elaboração simbólica. O imigrante em país de destino procura obter maior reconhecimento de sua identidade étnica e aceitação das diferenças culturais.

Os fluxos imigratórios recentes criam novas dinâmicas aos territórios, provocando integração, peculiaridades e contradições, gerando necessidade de políticas públicas apropriadas às novas realidades.

Palavras-chave: Fluxos e destinos migratórios. Espaços sociais. Relações interculturais. Feminização. Cidadania transnacional

\footnotetext{
${ }^{1}$ Doutora em História Social. Investigadora e Diretora de Publicações do CERUUSP(Centro de Estudos Rurais e Urbanos - Universidade de São Paulo/Brasil. Temas de pesquisa: questões migratórias, questões urbanas, gênero e fronteiras culturais. Possui livros e artigos publicados em revistas científicas. E-mail: ctlucena@uol.com.br
} 
ABSTRACT

\section{Latin American Immigrant flows: transnational citizenship}

This article discusses the immigration flows from South and Center American into a globalization context. It presents some results of investigations on women within a metropolitan and borderline context. Peruvian women in the São Paulo city, and Nicaraguan women in Costa Rica are the content of the analysis. The criterion of choice of the immigration flows was based in two types of the most preferred destinations among Latin American people nowadays. To check the feminization in immigration movements added to the forms of survival of these women in their respective receptor spaces, the re-significations of the citizenship concept from interethical and intercultural relationships are some of the purposes. In social spaces, it is constructed the networks and bonds that cross political frontiers when setting multiple familiar, social, political, religious and cultural relationships. By its turn, the transnational process resulting from globalization is permeated by the immigration controls, conflicts, the inspections in international borders, thus generating new social-economic issues. Life experiences of some actors disclosed how the concept of citizenship is reconstructed into the cultural diversity, how it interact upon the coexistence with different cultures, the confronts in social spaces that records new movements in continuity to the concerns that the respective groups already had at their territory of origin.

The metropolis and frontiers in Latin America have been presenting as spaces for a meeting place between the local and the global, of exchange, conflicts, and intercultural relationships. Nicaraguan women migrated to Costa Rica in search for higher salaries, better health services, but many times, the disenchantment motivates their returning. As to the Peruvians installed in the city of São Paulo, they use the food of their origin country as an assertive strategy to make a living and in order to be culturally recognized in their destination country. Upon the cultural construction of the citizenship, the immigrant points out everything with symbolic elaboration. The immigrant in his destination country seeks to attain a stronger recognition of his ethical identity and acceptance of the cultural differences.

Immigration flows in the present context create new dynamics to the territories, thus causing integration, peculiarities and contradictions, generating the need for appropriate public policies to the new realities.

Keywords: Flows and migratory destinations. Social spaces. Intercultural relationships. Feminization. Transnational citizenship 


\section{Apresentação}

O mundo atual se constitui um campo global de interações sociais estruturadas por processos demográficos, culturais, econômicos e políticos que ocorrem entre sociedades. Essas interações configuram os atuais movimentos populacionais de tal forma que na atualidade se pode falar de uma época migratória (CASTLES \& MILLER, 1993). Assim, os protagonistas buscam outros lugares para morar, desdobram suas opções, realizam deslocamentos internos dentro do próprio país, mobilidades de longa distância em busca de países e de cidades que ofereçam melhores oportunidades e, a partir dos anos de 1990, foram intensificados os fluxos para zonas fronteiriças.

O presente artigo é resultado de investigações realizadas na última década: uma pesquisa sobre a integração de peruano(a)s na cidade de São Paulo e um estudo sobre movimento populacional em fronteira Amazônica $^{2}$. As experiências investigatórias possibilitaram visitas a outros espaços fronteiriços e diálogos com investigadores da América do Sul e Central. As reflexões confirmaram que os destinos de latinoamericanos para contexto metropolitano e fronteiriço, são os dois tipos mais favoritos; dessa maneira, as cidades e as fronteiras tendem a se transformar em espaços globais.

Como eixo de análise, a presença feminina nos fluxos imigratórios, as formas de sobrevivência dessas mulheres nos respectivos territórios receptores, as re-significações do conceito de cidadania a partir das relações interétnicas e interculturais em espaços transnacionais, são temas a serem tratados. Assim, após contextualizar o fenômeno imigratório latino-americano os tipos mais favoritos de destino serão foco de debate. A metrópole por ser apontada como um local privilegiado de concentração das atividades econômicas e a zona fronteiriça como um local de instabilidade, territórios que tendem a se transformar em espaços globais.

No entendimento dessa problemática, mulheres peruanas instaladas em São Paulo e mulheres nicaragüenses na fronteira Nicaragua-Costa Rica

\footnotetext{
${ }^{2}$ O projeto sobre "Integração de peruanos em São Paulo" é uma das atividades de investigação desenvolvida no CERU, desde 2007 aos dias atuais. O projeto integrado sobre "Movimento populacional na fronteira Amazonica: Brasil, Peru e Bolívia" foi realizado nos anos de 2007 a 2009 com apoio da AECID (Espanha).
} 
são as protagonistas. As experiências de vida de pessoas investigadas evidenciaram como o conceito de cidadania é re-construído nas respectivas modalidades migratórias, como vêm reagindo diante da diversidade cultural, dos confrontos em espaços sociais que registram novos movimentos em continuidade à problemática que os respectivos grupos já possuíam no território de origem.

\section{Contexto imigratório contemporâneo}

Os países da América do Sul e América Central que na escala de desenvolvimento se colocam abaixo dos países da América do Norte e Europa, ao mesmo tempo em que são emissores de fluxo migratório para os países desenvolvidos também são receptores dos fluxos internos do próprio continente sul-americano. Desse modo, é possível constatar que os países em desenvolvimento tem sido uma alternativa aos movimentos migratórios que se dirigiam aos países da Europa e América do Norte. Os patrulhamentos implantados nos países mais ricos referente à entrada de pessoas dos países mais pobres, sem dúvida, é uma das causas desse fenômeno. Estudo recente realizado pela Organização Internacional para a Migração (OIM), diz que 70\% dos movimentos populacionais ocorrem entre países em desenvolvimento, as chamadas migrações Sul-Sul, isso se deve, principalmente, à criação pela economia globalizada de ilhas de prosperidade em regiões em desenvolvimento (ADGHIRNI, 2008). Na segunda metade do século XX, a América do Sul e América Central viveram os êxodos de populações rurais que deram origem às grandes concentrações urbanas. Palácios diz: "se calcula que só entre 1930 a 1990 a migração do campo para cidade mobilizou cerca de 100 milhões de pessoas dentro da América Latina e Caribe. Hoje quase $70 \%$ de sua população reside em zonas urbanas" (2004, p.18). Partindo das novas dimensões atribuídas pela economia global, se faz necessário uma nova reavaliação sobre as tendências de movimentos migratórios no tempo presente, principalmente, aos países da América Latina (PATARRA, 2005), que diante da competitividade do mercado enfraqueceu suas possibilidades de geração de empregos e de renda, não garantindo desempenho necessário para o seu desenvolvimento.

No movimento migratório observado dentro da própria América Latina, os países mais procurados são: Brasil, Argentina, Venezuela e 
México. Em relação aos destinos migratórios de sul-americanos nos anos 2000, já aponta a opção pelo Brasil. O desenvolvimento econômico transformou países que antes eram plataformas de trânsito rumo ao mundo rico em destino final. Martin, peruano que vive em São Paulo desde 1995, sobre sua história de vida, comenta: "o Brasil ia ser um ponto para ir para Inglaterra, mas acabei ficando por aqui [São Paulo] $]^{3, "}$.

Faz parte ainda, dos deslocamentos o grupo de mulheres e meninas que são destinadas à prostituição e outras formas de exploração de trabalho. Um grande número entra cada ano na Europa, como conseqüência de tráfico com fins sexuais, são provenientes da América do Sul e Central. Redes de mulheres provenientes da Colômbia e da República Dominicana são transladadas às regiões fronteiriças na América Central, para oferecer serviços como parte de atividades de exploração sexual comercial (MORALES, 2010). A cada ano, cerca de 60 mil brasileiros são vítimas das redes internacionais de tráfico de pessoas, e têm como principais destinos a Espanha, Portugal e Suíça, segundo dados divulgados em agosto de 2010 pela Secretaria Nacional da Justiça (SNJ). Os primeiros resultados do I Plano Nacional de Enfrentamento ao Tráfico de Pessoas (2008 e 2009) mostraram que $80 \%$ dos brasileiro(a)s deportados pela Espanha eram imigrantes ilegais relacionados a algum tipo de crime de tráfico de pessoas, especialmente destinados à exploração sexual (BLANKENDAAL, 2011).

Em várias nações, as parcelas de remessas recebidas pelos emigrantes apontam uma porcentagem representativa do PIB. Segundo Canclini vivem nos EUA, na Europa ou em outras nações latino-americanas, $15 \%$ dos equatorianos e aproximadamente um décimo dos argentinos, colombianos, cubanos, mexicanos e salvadorenhos. Afirma: "A América Latina não está completa na América Latina. Sua imagem é devolvida por espelhos diversos no arquipélago das migrações" (2008, p. 25). Acrescenta: "o latino americano anda à solta, transborda seu território, segue à deriva em rotas dispersas” (2008, p. 27).

O aumento de fluxos imigratórios de sul e centro americano no contexto da globalização tem sido objeto de estudos que apontam para sua diversidade, significados, implicações, contradições e múltiplos

\footnotetext{
${ }^{3}$ Entrevista coletada na av, Rio Branco, São Paulo, 2008.
} 
desdobramentos. Nesse cenário da globalização as modalidades migratórias devem ser revistas, há necessidade da incorporação de novas dimensões explicativas para dar conta do fenômeno denominado imigrações internacionais. Dessa maneira, o entendimento dos fluxos de pessoas entre países e continentes, passa pelo reconhecimento de que na migração internacional contemporânea estão envolvidos fenômenos distintos e com grupos sociais e implicações diversas (PATARRA, 2006).

Nessa direção, os estudiosos levam em conta alguns aspectos relevantes, dentre eles: intolerâncias étnicas, aceleração das migrações, construção da cidadania, feminização, interculturalismo e transnacionalismo. Além de estudos sobre a problemática das teorias de migração internacional, outras contribuições como a Sociedade de Rede de Castells e as Cidades Globais de Saskia Sassen ajudam na compreensão dos efeitos das transformações da sociedade global e dos intensos fluxos migratórios que estão modificando a cartografia mundial. As redes sociais e familiares são determinantes em todo circuito migratório transnacional, compreendem laços que conectam os imigrantes, os antigos migrantes e não migrantes na região de origem e de destino. Castells (1999) ao discutir as redes afirma que a restruturação do mundo capitalista de produção se expressa na globalização e nos mercados transnacionais, com isso provocou uma aproximação do local com o global e das economias das diversas nações.

Para as mulheres da América Latina, as últimas décadas tem sido das feminizações: da pobreza, do setor terciário e das migrações. É a feminização da mão-de-obra, entendida como geração de um mercado transnacional composto por uma rede de mulheres que desempenham serviços domésticos, atendimento em lojas, trabalhos em bares e restaurantes, trabalhos ambulantes e informais, etc. Segundo Palácios: "a tendência internacional nos mostra que as mulheres alcançam na migração internacional 48\% dos aproximadamente 20 milhões de latinos e centro americanos que se encontram fora de seu país de origem" (2004, p.17).

Os processos de feminização das migrações não são homogêneos, os fluxos variam dependendo das singularidades dos mercados de trabalho dos países emissores e receptores. Os processos de migração interna vivida na América Latina vêm mostrando a presença de 
mulheres nas capitais mais importantes, mulheres que chegam de regiões mais pobres e assumem tarefas consideradas femininas.

A tendência em contexto atual demonstra cada vez mais a presença de mulheres nos diferentes tipos de fluxos migratórios. São inúmeros casos de mulheres que se deslocam desacompanhadas de companheiros, solteiras e casadas, que migram deixando o companheiro no país de origem. Cada vez mais, saem de maneira autônoma. Maria é um exemplo de imigrante que tomou a iniciativa de migrar deixando o marido para trás. Veio de Lima para São Paulo em 1998, esperando um filho. O marido permaneceu no Peru a espera do nascimento da criança, migrou depois de dois anos, quando o filho já possuía nacionalidade brasileira e a mulher havia conquistado o visto de permanência. As mulheres nicaragüenses na prática de imigração temporal se deslocam para Costa Rica deixando os filhos no país de origem produzindo um formato de família com integrantes divididos entre as comunidades de origem e de destino.

Os efeitos sócio-culturais dos atuais processos de internacionalização provocam uma redefinição e reformulação do conceito de cidadania. Os novos deslocamentos dos grupos humanos por meio de novas identidades e de novas propostas de vida estimuladas pelo contexto atual global ampliam as trocas culturais, e ao mesmo tempo, ampliam os conflitos baseados na interculturalidade. O conceito de cidadania não deve permanecer baseado em concepções uniculturais e uniétnicas, urge pensar hoje em uma nova configuração ao conceito e aceitá-lo dentro de re-significações a partir das relações interculturais e interétnicas (VARGAS LLOVERA, 2007). A cidadania é um mecanismo de poder através do qual se definem as relações do indivíduo no interior de uma sociedade, permitindo ou restringindo o acesso aos direitos civis, políticos e sociais. Assim, os direitos humanos acompanhados de solidariedade podem dar uma identidade renovada às nações, permitindo a redução de conflitos surgidos a partir das diferenças. Nos enfrentamentos "chega-se assim, a artefatos, aparatos, armaduras para lidar com poderes, assimetrias, discriminações" (CASTRO, 2000, p.52). Na prática, as relações vêm acompanhadas de discriminação e de intolerância, dificultando os acessos aos estrangeiros.

Por transnacional, entende-se o processo pela qual os imigrantes elaboram e sustentam relações sociais multientrelaçadas, que juntam o 
contexto de origem e o receptor. Essas relações são construídas por meio das políticas dos estados nacionais com as redes, tendo em vista a construção de cidadanias. Além das uniões que conectam as regiões de emigração e imigração, surge o conceito de espaços sociais transnacionais, que busca reconhecer as práticas que conectam os mundos dos migrantes, dos que permanecem no lugar de origem, assim como as instituições e redes que os conectam. Nesses espaços se constroem laços que cruzam as fronteiras políticas ao estabelecer múltiplas relações familiares, sociais, políticas, religiosas e culturais (FAIST, 2000).

A transnacionalização, resultado da globalização, por sua vez, é permeada por pressões migratórias, por conflitos, por fiscalizações em fronteiras internacionais, gerando novas questões sócio-econômicas. Pobreza, estranhamentos e confrontos sociais transformam-se em sintomas de desigualdades, em preconceitos e intolerâncias na sociedade mundial contemporânea. Nesse contexto milhares de atores se deslocam em busca de novas oportunidades, e enfrentam barreiras diante das diversidades e das políticas imigratórias.

A seguir dois tipos de destino migratórios serão objeto de análise com intuito de ressaltar peculiaridades das imigrações internacionais recentes.

\section{Fronteiras: espaços receptores de imigrantes}

As fronteiras internacionais, espaços que permaneceram desapercebidos por muitos anos com uma visão vinculada à defesa dos territórios, nos anos recentes não têm escapado dos efeitos da globalização social, cultural e econômica. O movimento populacional na fronteira apresenta singularidades em relação às migrações internacionais de longa distância e às migrações em contextos nacionais do interior para os grandes centros. Entende-se por movimento populacional fronteiriço os deslocamentos nos limites entre países de fronteira e a chegada de novos habitantes para a região de fronteiras. Os movimentos populacionais em fronteiras são marcados por questões sociais, políticas e econômicas 
Na América Latina o comércio e a internacionalização de mercadorias encontra terreno fértil nas fronteiras, essa economia específica passa a ser uma atração para população migratória, convertendo a fronteira em ponto de encontro, de intercâmbios e de separação interestatais (CARRIÓN, 2013). A região transfronteiriza é precisamente um espaço de contradição que cruza o local e o global. É uma região que permite perceber uma estrutura em que a fronteira funciona como limite, como território econômico e cultural. Região transnacional integra espaços territoriais de dois ou mais países, dentro de um sistema de relações que podem ser tanto regulares como informais por meio da formação de redes e diversos canais de interconexão que pressionam sobre as dinâmicas e as decisões institucionais no manejo das relações entre os Estados centrais e os poderes locais. As redes sociais transfronteiriças tendem a ficar conectadas a partir de olhos transversais que organizam interações para as populações em trânsito( MORALES, 2013).

As zonas fronteiriças são campos de choques políticos e simbólicos e ao mesmo tempo espaço de misturas culturais e de formas de integração variadas. Se a fronteira cultural é trânsito e passagem, que ultrapassa os próprios limites que fixa, ela proporciona algo novo, a mistura, a troca, a mestiçagem cultural e étnica (PESAVENTO, 2002).

Ao estudar as fronteiras (Brasil, Paraguai e Argentina), Rabossi argumenta que as inter-relações são tantas, que o limite internacional pode parecer uma abstração em um espaço urbano contínuo. Assim, diz: "não podemos nos esquecer que é precisamente pela presença de tal limite que esse movimento acontece" (2011, p.44). Os imigrantes brasileiros que conseguiram ascender socialmente nas últimas décadas controlam setores não só da economia, mas da política e da cultura em algumas cidades paraguaias (ALBUQUERQUE, 2011). O caso da imigração fronteiriça, apesar de sempre ter existido, observa-se sua intensificação nos países sul-americanos a partir de 1990, devido à integração econômica promovida pelo Mercosul e pelas políticas dos Estados e, ainda, pelo agravamento de dificuldades regionais crescentes (KANASHIRO, 2007).

As fronteiras amazônicas foram constituídas historicamente por camadas culturais temporais mesclando etnias e marcadas por tratados limítrofes entre Estados. A exploração da borracha, no final do séc. XIX e início do XX marcaram movimentos, negociações e redefinição 
de linhas delimitadoras entre Brasil, Bolívia e Peru (LUCENA, 2013). A partir de 1990 com a construção da Rodovia Transoceânica que conecta a cidade de Rio Branco ao Pacífico, abre espaço para um comércio entre Brasil e Peru e as relações interfronteiras que durante anos eram produto de um cotidiano embasado nas relações informais e nas práticas culturais locais, a partir de 2010 as fronteiras se transformam em uma porta de entrada ao Brasil para imigrantes internacionais, principalmente para haitianos.

$\mathrm{Na}$ América Central, a migração fronteiriça se concentra em: Guatemala-Belice, Guatemala-México, Nicarágua-Costa Rica e Costa Rica-Panamá. Todavia, o maior fluxo de pessoas se concentra na fronteira Nicarágua-Costa Rica. A presença de instigantes estudos sobre o deslocamento recente de mulheres nicaragüenses para Costa Rica e caracterização do território como "espaço transfronteiriço", foram fatores que motivaram a escolha do espaço para reflexão. Tratase de uma zona fronteiriça, que, nas últimas décadas vem passando por mudanças; a nova imigração transformou o território em "espaço transfronteiriço" ou seja, um espaço composto por diferentes redes sociais de transportes e por atividades produtoras conectadas por meio de uma acumulação transnacionalizada de capital. O perfil dos migrantes nicaragüenses se diferencia segundo o destino, um perfil mais urbano faz opção pelos Estados Unidos, enquanto os de origem rural se destinam a Costa Rica em uma emigração de caráter temporal (MORALES, 2010).

O Censo Nacional de População de Costa Rica registra uma importante e crescente presença de mulheres nos movimentos migratórios. $51 \%$ da população migrante nicaragüense é mulher, na faixa de 33 anos de idade, com escolaridade secundária incompleta, 51,8\% são solteiras e 56,1\% são indocumentadas (SOLIS apud MORALES, 2010, p.19).

A situação e condição que experimentam as mulheres migrantes em sua trajetória migratória, através das localidades e pontos que conformam as zonas fronteiriças, estão determinadas por três aspectos: a condição de gênero, os níveis educativos e a migração por via irregular, geralmente em condição de indocumentação migratória (MORALES et al, 2010, p.20).

Alguns fatores fizeram da Costa Rica a grande receptora de nicaragüenses, a zona fronteiriça começou a adquirir dinamismo com a 
finalização do conflito armado que afetou a Nicarágua num período compreendido de 1970 até início dos anos de 1990, a ampliação de turismo e de atividades agrícolas na Costa Rica ampliaram o interesse de moradores do país vizinho pela região. Assim, "a população que habita a fronteira da Nicarágua é propensa a emigrar à Costa Rica" (PATIÑO, SOLIS, GALO, 2008, p. 21). Diversos estudos vêm revelando o caráter temporal da migração transfronteiriça, os deslocamentos, as trajetórias, o apoio encontrado nas redes, a intenção de se inserir em zonas urbanas e áreas metropolitanas de Costa Rica, a utilização da fronteira como corredor de passagem. A região fronteiriça é ante-sala e corredor social metropolitano (LORIA, 2002). As mulheres que buscam serviços como domésticas preferem emigrar para Costa Rica a ir para Manágua, por conta das diferenças salariais.

A migração é feita de forma individual e realizada em etapas, migra um membro da família e depois chegam os outros. A decisão de migrar de forma individual geralmente acontece quando o(a) protagonista já possui um familiar instalado na região de destino. Os homens arriscam a todo tipo de atividades agrícolas e industriais, e as mulheres, aos trabalhos domésticos e ao empacotamento de frutas e tubérculos.

As mulheres migram sozinhas, tanto as solteiras como as casadas, muitas partem deixando marido e filhos para trás. Quando saem com os maridos, o homem se dedica ao trabalho agrícola e a mulher ao doméstico. Algumas mulheres arriscam desenvolver tarefas em plantações de café, banana, melão, abacaxi e mandioca. A narrativa a seguir demonstra um caso de que a mulher migrou para a fronteira acompanhada do marido. Assim, comenta: "Nos fuimos a Costa Rica, el rabajaba en una finca de banana y yo en otra pelando yuca...Trabajaba de 6 de la mañana a 8-9 de la noche, trabajando fuerte y llegava com calambres en las manos"(apud GIRARDI, 2009, p.73).

Patiño, Solis e Galo sobre a incidência da migração de mulheres em "Estudo exploratório y binacional" (2008) explicam que as nicaraguenses que migram para Costa Rica, muitas são provenientes de municípios localizados na zona Atlântica. A cidade de San Juan de Norte tem uma história caracterizada por diversos abandonos, outras provêm de Manágua e Leão, e procuram se fixam em locais que

\footnotetext{
${ }^{4}$ Entrevista publicada em Informe Regional de Trabajo y Familia, de autoria de Mara Girardi(PNUD-OIT). Manágua,abril 2009.
} 
imaginam encontrar uma melhor realidade de vida. Libéria, por exemplo, é um lugar "onde a maioria dos imigrantes são mulheres" (2008, p.21). Muitas mulheres dão preferência para a região norte e Atlântica, e se dedicam aos trabalhos poucos qualificados, outras utilizam o corredor agrícola da fronteira como estratégia de travessia e acabam desembocando nos trabalhos domésticos em San José, a capital, onde os nicaragüenses representam $11 \%$ da população total (2008, p.21). O estudo divulga ainda uma série de entrevistas coletadas com mulheres em zona de fronteira, mulheres assentadas em São José e com retornadas. As narrativas apontam os motivos da saída: a busca de melhores salários, serviços de saúde e, ainda, escapar da violência familiar, porém os desencantos e compromissos com o país de origem motivam retornos. É comum que as mulheres de fronteira lamentem sobre a falta de atenção a elas no que se refere à saúde pública de seu país, para serem atendidas, "tienen que ir a Costa Rica".

As migrantes instaladas em Costa Rica, em situação regular, encontram oportunidade de realizar o retorno temporal a Nicaragua. Assim, a construção de cidadania em espaço transfronteiriço, na perspectiva de imigração temporal, revela que, o território de origem é o lugar onde permanece toda ou parte da família e na maioria das vezes mantém como referência a casa de origem. A facilidade de idas e vindas não é concedida para aquelas que se encontram em situação irregular, nesse caso, nesse caso, a travessia por meio de "pontos cegos", lugares com baixa fiscalização. As mulheres retornam a casa de origem com mais freqüência que os homens, o compromisso com filhos e familiares deixados para trás alimenta o vai e vem. Assim comenta uma retornada temporal: No porque aqui em Nicarágua, tengo mis hijas y no puedo alejarme de ellas, tengo que estar yendo y venindo (apud PATINO, SOLIS y GALO, 2008, p.43)

As dificuldades ao fazer a travessia na fronteira, discriminação encontrada nas relações de trabalho e dificuldade para encontrar emprego, são motivos para retorno temporal ou definitivo. As retornadas alegam que o bater de porta em porta em busca de emprego de forma infrutífera, é um dos motivos que provoca o desgaste e até o retorno. A maioria não pensa em retorno definitivo, sobre essa expectativa, uma nicaragüense desabafa: "yo esperaba encontrar que la situación me cambiara, pero me cambió para atrás. Outra expressa: 
"si tanto me costó salir, si tanto me criticaram, como voy a llegar diciendo que fracasé”.(Apud PATIÑO, SOLIS e GALO, 2008, p.28).

Os (res)sentimentos dessas mulheres que se defrontaram diante da problemática migratória demonstram que os exercícios de cidadania e as experiências em espaço transfronteiriço apresentam instabilidade, traduzem resignação, frustração e ao mesmo tempo oportunidade de conquistar sustento.

\section{Fluxos imigratórios para região metropolitana}

A imigração dos países sul americanos para centros urbanos tem se intensificado a partir das últimas décadas do século $\mathrm{XX}$, principalmente a partir de 1990. A década de 1970, a década dos golpes militares na América do Sul, momento de otimismo em relação à economia brasileira, o governo militar promoveu uma política imigratória para atrair técnicos e profissionais de outros países, isso estimulou o deslocamento de chilenos, argentinos, uruguaios para o Brasil. Os anos 80 embora tenham sido considerados como "década perdida", percebe-se na ocasião um acentuado crescimento urbano, com o aumento dos fluxos migratórios para as metrópoles. As chamadas "cidades globais" constituem o local da concentração das atividades ligadas ao processo de dinamização das atividades econômicas (SASSEN, 1998). As cidades de São Paulo, do México e de Buenos Aires, são cidades que hoje assumem o papel de lugares procurados para novas opções de vida para esse contingente de emigrados da própria América. Em contexto metropolitano, o foco de análise prioriza, aqui, a cidade de São Paulo.

Segundo Silva (1999), baseando em dados colhidos no arquivo do Centro Pastoral dos latino-americanos entre os grupos atendidos pelo Centro, destacam-se bolivianos, peruanos, paraguaios, chilenos e $\operatorname{argentinos}^{5}$. A partir das redes de solidariedade, percebe-se que os sulamericanos, ao chegarem em São Paulo, alguns são acolhidos por familiares e amigos já instalados na cidade, todavia, a maioria procura as redes de solidariedade, como no caso o Serviço da Pastoral dos Migrantes; encontram lugar de acolhida, apoio para as questões de

${ }^{5}$ Ver Travessia, revista do migrante, o artigo de Sidney Antonio Silva: Hispanoamericanos em São Paulo. 
documentação e, ainda, proteção jurídica e psicológica. Os serviços promovem encontros por meio de reuniões e festas organizadas pelos coordenadores dos respectivos países: Peru, Chile, Bolívia e Paraguai.

A presença peruana em São Paulo remonta aos anos de 1980, embora tenha ficado mais significativa a partir de 1990. No final de 1988, a crise econômica, a violência terrorista e outros tantos problemas, levaram os peruanos a emigrar em busca de emprego e de proteção de vida. Em 1998, o consulado peruano registrou aproximadamente 10.000 peruanos em São Paulo, entre documentados e irregulares. O periódico El Comercio ${ }^{6}$ divulgou em 2007 que nos últimos quinze anos, 1.665 .000 peruanos saíram de seu país, sendo que 31.532 se dirigiram ao Brasil. O grupo instalado em São Paulo é heterogêneo, refletindo as hierarquias do país de origem. Composto por trabalhadores em geral, estudantes de pós-graduação, profissionais altamente qualificados em medicina e engenharia, vendedores de artesanato, trabalhadores em oficinas de costura, trabalhadores domésticos e os vendedores ambulantes e vendedoras de comida do país de origem.

Para compreender o significado que o conceito de cidadania assume na metrópole e as fronteiras mais sutis vivenciadas, é necessário levar em conta, as dificuldades na conquista de documentação, na aquisição de trabalho e nos benefícios sócioeconômicos, a tensão entre o discurso do Estado e a realidade enfrentada pelo grupo em diáspora. São muitas as estratégias utilizadas como forma de sobrevivência no país de destino.

Os peruanos em São Paulo destacam-se pelo nível elevado de escolaridade. Também chama a atenção o contingente de mulheres peruanas instaladas na metrópole paulista. De modo geral os comerciantes de artesanato são provenientes de regiões urbanas, Cusco, Arequipa e Puno, e vivem concentrados no centro da cidade. A investigação em São Paulo vem caminhando pela rota gastronômica, pelos rastros da "cozinha territorial", lugares em que a comida peruana é servida, restaurantes, festas, bazares e rua (LUCENA, 2008).

\footnotetext{
${ }^{6}$ www.elcomercioperu.com.pe/edicionOnline/Html/2007-01-11. Um millón 665 mil peruanos se fueron del país entre los años 1990 y 2005. Acessado em 12 de janeiro de 2007.
} 
Homens e mulheres tentam ganhar seu sustento por meio da culinária do país de origem, utilizam as singularidades como estratégia de inserção no país de destino e o apoio dos comensais que freqüentam os locais. Usam os saberes e sabores do país de origem, transforma a cozinha regional em cultura cosmopolita, em forma de reconhecimento e identificação, transformam o antigo focus de submissão em justaposição cultural.

Assim, para entender como a cidadania de um grupo de mulheres é construída no contexto metropolitano, além de compreender suas vivências, foi importante estabelecer um contraponto com as informações fornecidas por pessoas do universo masculino, tanto proprietários de restaurantes como comensais, com intuito de compreender os modelos de conduta, a formação de grupo minoritário e os sentimentos e ressentimentos que os indivíduos sentem em relação ao Estado e quanto a si mesmos. As frustrações ao exercer cidadania podem ser traduzidas em resignação, resistência ou solidariedade.

$\mathrm{Na}$ construção cultural da cidadania o imigrante acentua aquilo que a cultura tem de elaboração simbólica. Os hábitos alimentares fazem parte de um domínio que implica representações e imaginários, as pessoas, ao se deslocarem, transferem em suas bagagens suas práticas culturais e as utilizam no processo de inclusão no território de acolhida. Práticas como essas fazem com que atividades do passado e do presente se entrelacem a por meio de uma tradição que se atualiza nos pratos que são elaborados por imigrantes. Assim, a elaboração da comida serve para: cobrir determinadas necessidades básicas de subsistência dentro de uns parâmetros culturais, a partir dos quais o gosto adquire sua própria singularidade, ser comercializada, ofertada, àqueles que através da culinária se reencontram com seu país de origem, e também àqueles que pretendem experimentar novos paladares, integrar-se desde a especificidade no país de acolhida. David, vive em São Paulo há mais de vinte cinco anos, trabalha com artesanato na Rua 25 de Março. Quando indagado sobre sua busca pela comida peruana vendida na rua diz: Venho comer aqui[Av. Rio Branco] quando quero matar a saudades de meu país",7.

A comida marca diferenças, neste caso, a singularidade se converte em um eixo que serve para ser reconhecido e reconhecer-se, tanto em

\footnotetext{
${ }^{7}$ Entrevista coletada em calçada pública, no centro da cidade de São Paulo, 2008.
} 
relação a seu grupo de pertencimento como em relação ao novo contexto. Por meio da comida é possível perceber as desigualdades, regionalismos, diferenças e como o pluralismo cultural do país de origem é reproduzido no país hospedeiro.

As narrativas femininas de mulheres que circulam pelos eventos peruanos oferecendo sua habilidade gastronômica, são permeadas de elementos que projetam afirmação de identidade, discursos de identificação e de reconhecimento (LUCENA, 2011). O conteúdo identitário revela a re-configuração de seus sentimentos de pertença canalizados para a comida do país de origem, e são identificadas como boas profissionais e conhecedoras da gastronomia. A preparação de uma "comida territorial" constitui um ato simbólico no que diz respeito à manifestação dos sentimentos de pertença e, ainda, de construção de cidadania transnacional.

Cecília afirma: "Faço sobremesas peruanas para divulgar culinária de meu país. A melhor maneira de divulgar a cultura é pela comida".Vilma iniciou sua atividade de cozinheira vendendo pratos na rua, ao ser descoberta pelo cônsul peruano, teve oportunidade de avançar seus trabalhos. Sobre sua trajetória, comenta:

Trabalhei quinze anos vendendo comida peruana na Praça da República, até que um dia fui reconhecida pelo consulado. Ontem estive com o embaixador da Espanha. Sou cozinheira latina, recebi cartas de reconhecimento, esta [mostrando a carta] é de uma firma alemã[BASF]. Eles foram embora do Brasil para a Argentina e de despedida, comida peruana. ${ }^{8}$

Edgar chegou em 2004, hoje proprietário de restaurante, em sua fala comenta sobre a tradição da família na prática de fazer e de vender comida; no Peru, tias e cunhada trabalham no ramo. Uma das maneiras de arriscar a vida é lidar com culinária por meio de uma organização familiar. Em São Paulo, após tentativas fracassadas em comercio de artesanato, resolveu vender comida aos ambulantes da região da Rua 25 de Março. O comércio das marmitas foi ampliado e os comensais foram se multiplicando. Sobre isso comenta: "quando senti que as pessoas faziam fila na rua para comprar comida, senti que estava sendo valorizado e reconhecido". A partir daí, alimentou a idéia da

${ }^{8}$ Vilma: nasceu em Lima em 1953, chegou em São Paulo em 1980, com 27 anos e com segundo grau completo. Ao chegar, contraiu matrimonio com brasileiro, conquistando visto de permanência. Em São dedica-se à culinária do país de origem. Entrevista coletada em 2007. 
divulgação da cultura do próprio país e, por trás, uma estratégia de conseguir um sustento em terra estrangeira. Suas despesas atuais no restaurante são grandes: aluguel do espaço, impostos, água, luz, telefone, funcionários e contador, porém, está conseguindo atender com êxito sua clientela oferecendo uma variedade de mais de cinquenta pratos representativos de distintas regiões do Peru. Nos últimos anos os restaurantes de cozinha peruana são cada vez mais numerosos fora do próprio país, o que vem favorecendo aos imigrantes peruano(a)s ganharem a vida por meio da gastronomia. O restaurante de Edgar, ao lado de outros restaurantes latinos, são mencionados em guias de gastronomia da cidade.

As mulheres analisadas se encontram em diferentes situações no que se refere à permanência no Brasil. Duas delas conquistaram visto por conta do nascimento de filhos brasileiros. Assim, podem prestar serviços com registros em carteira de trabalho, porém, preferem a economia informal. Uma cozinheira que vende comida na rua, recém chegada em São Paulo, além de estar inserida na economia informal é indocumentada. Essas mulheres, embora sejam invisíveis aos olhos da sociedade local, uma vez, convertidas em cozinheiras, refletem que as diferenças culturais não são obstáculos para que encontrem uma forma de prestar serviços e sobreviverem na cidade receptora.

Entre os rapazes que buscam a comida "territorial" como forma de ganhar dinheiro, os documentados apostam em ascensão social, com perspectivas de montar seu próprio negócio. Os indocumentados enfrentam a vida com mais angustias e vivem à espera de uma anistia. Carmelo, que vive uma vida transitória, uns tempos cá e outros lá, todavia, dessa vez pretende ficar de vez no Brasil, comenta: "aqui é difícil para um estrangeiro arrumar trabalho. Agora vim com mais força para começar a trabalhar. Quando vim pela primeira vez me sentia triste, mas agora ao re-encontrar amigos me sinto mais tranqüilo",9.

As mulheres, embora muitas sejam independentes provedoras da família, trabalham como prestadoras de serviço, caminham junto das possibilidades e oportunidades. Sentem mais segurança as que estão instaladas no país receptor há mais tempo, as documentadas e, ainda, as que têm o apoio de redes ou patrões em suas atividades. $\mathrm{O}$ centro da

${ }^{9}$ Entrevista coletada em São Paulo, centro da cidade, em 2008. 
cidade de São Paulo registra hoje uma fisionomia de interculturalidade, território escolhido por diferentes grupos de imigrantes, marcado por misturas identitárias e de idiomas. "A região da Avenida Rio Branco é o coração dos peruanos", diz Martin, imigrante radicado em São Paulo desde 1995.

A cidade de São Paulo é uma das metrópoles latino americanas, centro privilegiado da economia transnacional e espaço específico para o destino dessa imigração internacional. A concentração de atividades econômicas é um dos aspectos que marcam as chamadas cidades globais (SASSEN, 1990).

\section{A construção cultural da cidadania}

As políticas do Estado confirmam as classificações hierárquicas dos indivíduos nos grupos minoritários, o reconhecimento de cidadania, geralmente acontece aos que são documentados e bem resolvidos nas relações de trabalho, esses atores conseguem ter uma relação melhor com o país de acolhida. Resta ao grupo desenvolver "o sentimento de solidariedade que tem por objeto fortalecer a relação de dependência entre o indivíduo e seu grupo de pertencimento" (KOUBI, 2001, p. 530). As redes são importantes na inserção e integração.

Os imigrantes em geral são unânimes em dizer que os discursos de integração elaborados pelos Estados não são viabilizados na prática, a regulamentação relacionada aos estrangeiros em geral favorece as pessoas de maior qualificação. Nas falas, as representações construídas entre imigrantes peruanos revelam um Brasil que oferece oportunidades de trabalho, de estudos e de uma vida melhor. No que se refere à instalação de negócios os homens encontram mais possibilidades e visibilidades que as mulheres, embora as mulheres sejam entendidas como disciplinadas no envio de remessas e articuladoras nas iniciativas de solidariedade, os homens acabam tendo mais espaço para dinamizar negócios transnacionais, sustentados por relações multientrelaçadas entre o país de origem e de destino. Encontram facilidade em conquistar a documentação por meio de casamento ou o nascimento de um filho em território brasileiro. Para os indocumentados, resta ainda a esperança de uma anistia para poder dinamizar seu espaço em terra brasileira. 
A imigração entre Nicarágua e Costa Rica aponta para uma migração temporária o que gera mudanças no interior da família, produzindo o que se denomina famílias transnacionais, divididas entre os espaços de origem e destino. Nesse tipo de família se observa o papel das mulheres nas relações transnacionais e articuladoras dos espaços transnacionais.

Nesse sentido, a relação entre grupos de imigrantes e a sociedade envolvente se dá entre culturas que afirmam que as identidades e as cidadanias são construídas no processo de integração na diversidade. Para Kymlicka (1996) a diversidade cultural surge da imigração. Os imigrantes costumam se unir em associações denominadas "grupos étnicos". O objetivo desses grupos é integrar-se na sociedade da qual fazem parte e buscam ser aceitos em pleno direito. Por meio de estranhamentos, de múltiplas representações, de combinações conflitantes e de novas configurações, mulheres e homens imigrantes vão re-dimensionando seus comportamentos em busca de reconhecimento. Barth afirma: "Assim, a persistência de grupos étnicos em contato implica não apenas critérios e sinais de identificação, mas igualmente uma estruturação da interação que permite a persistência das diferenças étnicas" (1998, p.196). O discurso da sociedade envolvente é permeado de preconceitos, que gera conflitos, organiza a exclusão, tenta impor nos diferentes o adormecimento de seus desejos, negar oportunidades e modelar suas condutas. Porém, nas representações dos entrevistados de região metropolitana a maioria fixa residência, são poucos os que retornam, consideram o país hospedeiro se constitui no local privilegiado para as atividades econômicas. A fronteira é um lugar de maior instabilidade de fluxos migratórios, o que provoca uma imigração na maioria das vezes com duração determinada.

\section{Considerações finais}

O país considerado mais forte economicamente, as metrópoles e as áreas fronteiriças são espaços sociais da economia capitalista transnacional, esses territórios representam os espaços da nova ordem global. A grande cidade é um centro privilegiado em contextos globalizados nessa era migratória. Dessa maneira, grupos estrangeiros reconhecidos legalmente, uma vez inseridos na sociedade receptora, 
desempenham papéis sociais e profissionais, participam de atividades e deixam marcas culturais. Os bem sucedidos viajam com freqüência ao país de origem, recebem familiares como visitantes, celebram suas festas, recebem produtos a serem utilizados e comercializados. Assim, metamorfoseiam-se identidades por meio de negociações móveis, para isso, diversas estratégias são utilizadas, tendo em vista a integração e a busca de cidadania transnacional. Porém, os grupos ilegais permanecem invisíveis, enclausurados na categoria de migrante.

As fronteiras são culturais, fazem parte do jogo das representações nacionais, regionais e locais, na perspectiva contemporânea deixa de ser um encerramento de um espaço e começo de outro, a fronteira passa a ser "um limite sem limites", é uma realidade transcendente que aponta para um além. A fronteira "pela sua condição de transcendência, que envolve o distanciamento e o estranhamento como atitude, e a ambivalência e a ambigüidade como condição de ser" (PESAVENTO, 2002, p.38).

As áreas fronteiriças constituem um campo instigante de investigação a partir do trânsito e passagem, que ultrapassam os próprios limites que ela fixa, proporcionam processos de integração transnacional. A associação entre fronteiras e formas de vidas no mundo contemporâneo se produz por meio de "culturas de fronteiras" (VALCUENDE, 1998), incide no caráter plural da significação da fronteira política nos limites do Estado. A zona fronteiriça entre Nicarágua e Costa Rica apresenta-se hoje como uma região que oferece inúmeros atrativos, um espaço impregnado de mobilidades e de corredor em busca de oportunidade de trabalho.

Os estudos em América Latina vêm mostrando que as mulheres desempenham papel importante em diversas etapas do processo imigratório, decisões familiares, exercem papel articulador nas iniciativas de solidariedade e redes sociais. A mobilidade feminina é impregnada de discriminação e de barreiras provenientes da opressão de gênero. Entende-se que a opressão do gênero feminino surge da supremacia masculina autorizada pela estrutura patriarcal, que legitima algumas práticas cotidianas. Mesmo diante do estigma de gênero e de nacionalidade e da manutenção em sociedade de destino as hierarquias de origem, existem hoje o reconhecimento e empoderamento de mulheres em contextos migratórios. 
Os fluxos imigratórios internacionais criam novas dinâmicas aos territórios, geram câmbios nas relações sociais e em particular no interior das famílias. O espaço transnacional é também intercultural, produzindo interação de pessoas e intercâmbio nas práticas culturais. As imigrações internacionais provocam integração, peculiaridades e contradições, gerando necessidades de políticas públicas apropriadas às novas realidades.

Para Canclini, existe hoje "integrações silenciosas, a América Latina está integrando-se culturalmente, e entrando em novos conflitos interculturais, por meio de processos não programados politicamente" (2008,p.127). As migrações recentes configuram objeto privilegiado de análise das desigualdades regionais crescentes em diferentes territórios dos países da América do Sul e Central, desigualdades essas que ocorrem num contexto de globalização das relações econômicas.

Diante dos diferentes caminhos de integração, a cidadania de imigrantes é construída na pluralidade cultural e nas fronteiras da inclusão e exclusão. Os processos imigratórios adquirem outro significado, além de pretender integração, reivindicam compromissos políticos tendo em vista uma cidadania com direitos de população imigrante no país de acolhida.

\section{Referências bibliográficas}

ADGHIRNI, Samy. "Migrações sul-sul já são metade no total". Folha de São Paulo. Caderno Mundo, 8 de junho, A-20, 2008.

ALBUQUERQUE, José Lindomar. "Fronteiras em movimento: os brasiguaios na região da Tríplice Fronteira". In: MACAGNO, Lorenzo et al (org). A tríplice fronteira: espaços nacionais e dinâmicas locais. Curitiba, Paraná: Editora UFPR, 2011.

BARTH, Fredrik. "Grupos étnicos e suas fronteiras". In: POUTIGNAT, Philippe; STRIFF-FENART, Jocelyne. Teorias da etnicidade. São Paulo: UNESP, 1998. 
BLANKENDAAL, Stijntje. "O duro caminho de volta". [Revista]Carta Capital. Edição 664, 21 de setembro de 2011.

CANCLINI, Nestor Garcia. Latino-americanos à procura de um lugar neste século. São Paulo: Iluminuras. 2008.

CARRIÓN, Fernando. La violência fronteriza. In: CARRIÓN, Fernando (compilador). Seguridad, planificación, y desarrolto em las regiones fronterizas. Quito: FLACSO, Sede Ecuador: Centro Internacional de Investigaciones para el desarrollo (IDRC-CRDI), 2013.

CASTELLS, Manuel. A era da informação: economia, sociedade e cultura-a sociedade em rede. São Paulo: Paz e terra, 1999.

CASTLES, Stephen y MILLER, Mark J. The age of migration. New York: The Guilford Press, 1993.

CASTRO, Mary Garcia. "Transidentidades no local globalizado. Não identidades, margens e fronteiras: vozes de mulheres latinas nos EUA”. In: FELMAN-BIANCO, Bela; CAPINHA, Graça. Identidades: estudos de cultura e poder. São Paulo: Hucitec, 2000.

FAIST, Thomas. The volume and dynamics of International Migration and International social spaces. Oxford: Oxford University Press, 2000.

GIRARDI, Mara Informe Regional Trabajo y Família.(PNUD-OIT) Manágua, 2009.

Disponívelem:http:www.ucol.mx/egeneros/admin/archivos/el_impacto _dela_migracion.doc Acessado em 10 maio 2014.

KANASHIRO, Victor. "De amor e de esperança à terra desce". In: Sociologia ciência \& vida.ano I, n.6, 2007, p. 65-71.

KOUBI, Geneviève. "Entre sentimentos e ressentimentos: as incertezas de um direito das minorias". In: BRESCIANI, Stella \& NAXARA, Márcia(orgs). Memória e (res)sentimento Campinas, São Paulo: Unicamp, 2001.

KYMLICKA, Will. Ciudadania multicultural. Una teoria liberal de los direitos das minorias. Barcelona: Paidós, 1996. 
LORIA, Rocio. De Nicarágua a Costa Rica y a Nicarágua. La ruta critica de las mujeres migrantes nicaragüenses: uma mirada desde la zona norte fronteriza. San José, Centro de Estúdios y publicaciones. Alforja, 2002.

LUCENA, Célia Toledo. "As maneiras de fazer e identidades de mulheres imigrantes". In: MAZZA, Débora; Von SIMSON, Olga (Orgs). Mobilidade humana e diversidade sociocultural. Jundiaí, SP: Paco Editorial: 2011.

LUCENA, Célia Toledo. Saberes e sabores do país de origem como forma de integração. In Cadernos CERU, São Paulo: CERU/USP, v. 19, n.1, junho de 2008.

LUCENA, Célia Toledo. Fronteras en movimiento y los movimientos en la frontera. In: CARRIÓN, Fernando (compilador). Seguridad, planificación, y desarrolto em las regiones fronterizas. Quito: FLACSO, Sede Ecuador: Centro Internacional de Investigaciones para el desarrollo (IDRC-CRDI), 2013.

MORALES, Abelardo et al. "Migración y salud em zonas fronterizas: Nicarágua y Costa Rica". Série Población y desarrolo, 94, CELADE/CEPAL, Santiago, Chile, 2010.

MORALES, Abelardo. Territórios y espacio social: población y sociedad em fronteras y espacios transfronterizos. Una aproximacióin desde América Central. In: CARRIÓN, Fernando (compilador). Seguridad, planificación, y desarrolto em las regiones fronterizas. Quito: FLACSO, Sede Ecuador: Centro Internacional de Investigaciones para el desarrollo (IDRC-CRDI), 2013.

PALACIOS, Patrícia Balbuena. "Feminización de las migraciones". In Globalización, migración y direchos humanos. Ecuador, Quito:Universidad Andina Simon Bolívar, 2004.

PATARRA, Neide Lopes. "Migrações internacionais de e para o Brasil Contemporâneo, volumes, fluxos, significados e políticas". São Paulo em perspectiva, v.19, n.3, p.22-33,jul/set, formato PDF, 2005. 
PATARRA, Neide Lopes. Migrações internacionais: teorias, políticas e movimentos sociais. IN: Estudos Avançados.USP/IEA, vol.20, n.57. p.7-24. Maio/Agosto 2006.

PATIÑO, Marisol, SOLIS, Adília, GALO, Claudia. Estúdio exploratório y binacional (Nicarágua y Costa Rica) sobre la incidencia de la migración en las mujeres. San José: UNFPAOIM,2008.Disponívelem:http.//www.iom.int/jahia/webdav/sha $\mathrm{red} / \mathrm{shared} / \mathrm{minsite} / \mathrm{media} /$ docs/reports/informe. Acessado em 13 maio 2014.

PESAVENTO, Sandra Jatahy. "Além das fronteiras". In: MARTINS, Maria Helena (org). Fronteiras culturais. São Paulo: Ateliê editorial, 2002.

RABOSSI, Fernando. "Como pensamos a tríplice fronteira?" In; MACAGNO, Lorenzo et al (org). A tríplice fronteira: espaços nacionais e dinâmicas locais. Curitiba, PR: Editora UFPR, 2011.

SASSEN, Saskia. As cidades na economia mundial. São Paulo: Studio Nobel, 1998.

SILVA, Sidney Antonio. "Hispano-americanos em São Paulo". Travessia. Revista do Migrante, CEM, São Paulo: ano XII, n. 33, janeiro-abril, 1999.

Un millón 665 mil peruanos se fueron del país entre los años 1990 y 2005.

www.elcomercioperu.com.pe/edicionOnline/Html/2007-01-11.

Acessado em: 12 de janeiro de 2007.

VALCUENDE, José Maria. Fronteras, territórios e identificaciones colectivas. Sevilla: Fundacíon Blas Infante, 1998.

VARGAS LLOVERA, Maria Dolores. "Ciudadania transnacional o la negación de la ciudadania: los inmigrantes un debate abierto". Atas do VII reunião de Antropologia do Mercosul. Desafios Antropológicos(CDROM),2007. 